\title{
Estimating a global demand model for soybean traffic through the Panama Canal
}

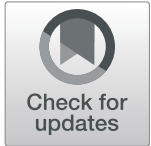

\author{
Javier Ho ${ }^{*}$ D and Paul Bernal
}

\author{
* Correspondence: jho@pancanal. \\ com \\ Panama Canal Authority, Balboa, \\ Ancon, Panama
}

\begin{abstract}
This study attempts to fit a global demand model for soybean traffic through the Panama Canal using Ordinary Least Square. Most of the soybean cargo through the interoceanic waterway is loaded on the U.S. Gulf and East Coast ports -mainly destined to East Asia, especially China-, and represented about 34\% of total Panama Canal grain traffic between fiscal years 2010-19. To estimate the global demand model for soybean traffic, we are considering explanatory variables such as effective toll rates through the Panama Canal, U.S. Gulf- Asia and U.S. Pacific Northwest- Asia freight rates, Baltic Dry Index, bunker costs, soybean export inspections from the U.S. Gulf and Pacific Northwest, U.S. Gulf soybean basis levels, Brazil's soybean exports and average U.S. dollar index. As part of the research, we are pursuing the estimation of the toll rate elasticity of vessels transporting soybeans via the Panama Canal. Data come mostly from several U.S. Department of Agriculture sources, Brazil's Secretariat of Foreign Trade (SECEX) and from Panama Canal transit information. Finally, after estimation of the global demand model for soybean traffic, we will discuss the implications for future soybean traffic through the waterway, evaluating alternative routes and sources for this trade.
\end{abstract}

Keywords: U.S. Gulf, U.S. Pacific Northwest (PNW), Soybean export inspections, Soybean basis, Interroute, Interport, Inter-origin, Panama Canal

\section{Introduction}

From fiscal year 1987 up to fiscal year 2001, the grain category -including soybeans-, was the main commodity through the Panama Canal in terms of cargo tons. ${ }^{1}$ However starting from fiscal year 2002, containerized cargo and -since fiscal year 2017 and coinciding with the expanded Panama Canal-, petroleum and products, are disputing the number one cargo spot. In terms of the grain cargo flow through the waterway, soybean has become the dominant grain flow since fiscal year 2009, overtaking corn as the main grain commodity. ${ }^{2}$ The main grain trade for the Panama Canal is represented by the U.S. Gulf and East Coast- Asia trade route. Regarding the soybean trade flow in particular through the interoceanic waterway, the majority is loaded on the U.S. Gulf

\footnotetext{
${ }^{1}$ Fiscal Year of the Panama Canal runs from October 1 of a previous calendar year to September 30 of the following calendar year.

${ }^{2}$ Exceptions are in fiscal years $2016-17$ because of the good sorghum flows to China from the U.S., and fiscal year 2018 due to the retaliations from the trade war between the U.S. and China.
} 


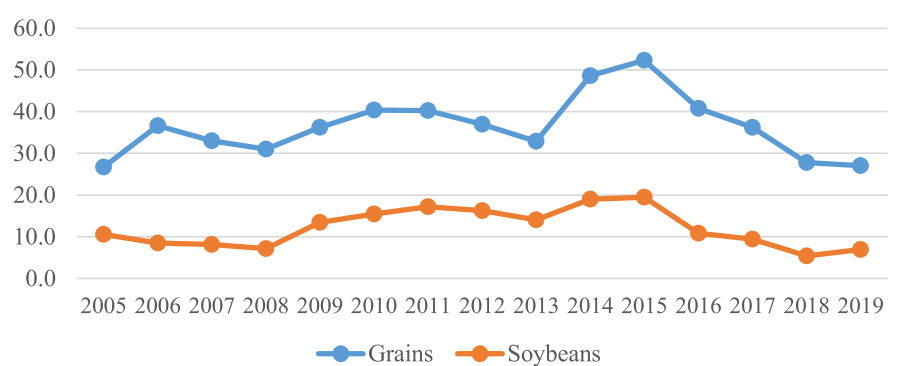

Fig. 1 Grain and Soybeans Flows through the Panama Canal. Millions of Long Tons. Source: Panama Canal internal database

and East Coast ports and is mainly destined to East Asia, especially China, the world largest importer of the oilseed. The soybean trade represented close to $34 \%$ of total Panama Canal grain traffic between fiscal years 2010-19. In general, grains and soybeans in particular have been declining, specifically since fiscal year 2015 (Fig. 1). Similarly, total toll amount of vessels carrying soybeans through the Panama Canal follows closely the amount of soybean cargo, displaying the same general declining trend since fiscal year 2015 (Fig. 2). At the same time, it is important to keep in mind that, between fiscal years 2015-19, the U.S. Gulf and East Coast to East Asia (China, Japan, South Korea and Taiwan) represents about $74 \%$ of total soybeans movements through the Panama Canal, in which China represents close to $50 \%$ of total soybeans flows during the same period. What factors may explain the declining movements of grains, especially the soybean flow through the Panama Canal during the period? A few specific studies have been advanced, providing some insights to answering this important question for the Panama Canal.

According to Wilson and Ho (2018), the grain trade originating in the U.S. Gulf and East Coast to Asia through the waterway --including soybeans-- faces inter-origin competition stemming from increased production and exports from sources different from the United States, namely Brazil and Argentina for soybeans. According to the U.S. Department of Agriculture (USDA), Brazil is the main soybean exporter in the world since marketing year 2011/12. ${ }^{3}$ Because of geography, most soybean shipments originating from Argentina and Brazil destined to Asia bypass the Panama Canal. On the other hand, Skadberg et al. (2015) state what they call "intermarket competition" between the U.S. Gulf versus the U.S. Pacific Northwest (PNW) port regions for grains in the U.S. hinterland but defined as "interport competition" by Wilson and Ho (2018). In this competition for grains departing from the U.S. interior to either the U.S. Gulf or the PNW, competitive barge rates to the U.S. Gulf ports, port costs and rail rates both to the U.S. Gulf and PNW are important factors in the determination of grains flows into either region. After reaching the U.S. Gulf or the PNW elevators, U.S. grains may be exported to Asia and other destinations. In the case of the PNW, it is a direct, shorter route to Asia and the West Coast of Central and South America, an origin that competes against the Panama Canal grain flows originating from the U.S. Gulf. Freight rate differentials between vessels departing the U.S. PNW or the U.S. Gulf are regularly

${ }^{3}$ Brazil as the main soybean exporter in the world is regularly mentioned in news outlets, publications and academic reports. Also, U.S. Department of Agriculture's Oilseeds: World Markets and Trade, USDA-FAS of May 2016 provides proof of this statement. 


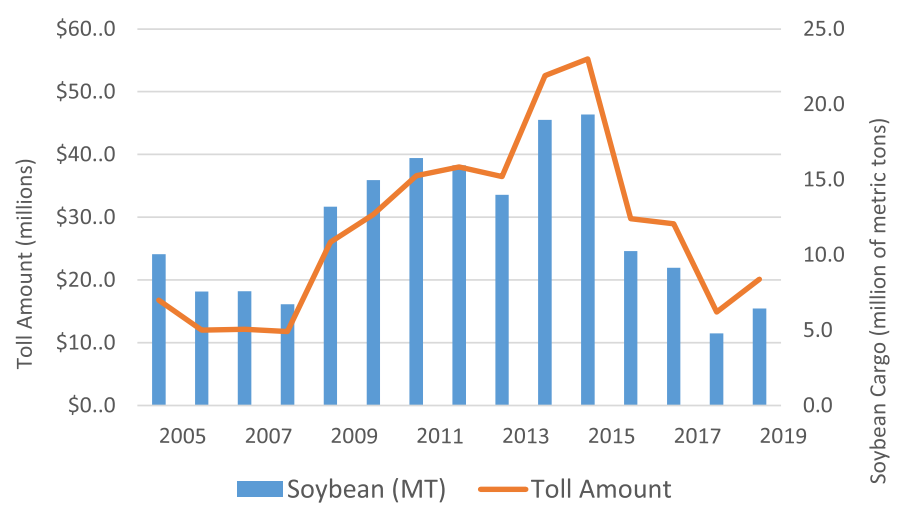

Fig. 2 Soybeans Flows and Total Toll Amount for Vessels Carrying Soybeans. Source: Panama Canal internal database

reported by the United States Department of Agriculture ${ }^{4}$ and are considered one of the factors in the decision to ship grains to either region in connection with voyage and final destination landed cost.

Related to "interroute competition" as stated by Wilson and Ho (2018), grains from the U.S. Gulf to East Asia may be hauled either through the Panama Canal or alternative routes including the Cape of Good Hope. ${ }^{5}$ In this interroute competition, factors such as ocean freight rates, timecharter, fuel costs and Panama Canal considerations such as toll rates and delays may sway the route choice from a voyage cost perspective. However, in attempting to explain grain bypasses from the U.S. Gulf and East Coast to East Asia mainly through the Cape of Good Hope route, Ho and Bernal (2019) estimated that the draft variable, a proxy for cargo intake, was the only statistically significant predictor explaining the decision to use either the Panama Canal route or alternatives, while voyage cost variables such as Panama Canal tolls, timecharter, bunker cost and Canal Water Time (CWT) were not statistically significant. ${ }^{6}$ They also highlighted the difficulty of Panamax vessels of securing transit slots using the reservation system and the fact that many Panamax vessels do not fulfil the towing and mooring requirements to transit the expanded Canal, therefore hindering the participation of Panamaxes through the Neopanamax locks. ${ }^{7}$ At the end, they recommended additional studies to better understand the factors that go into play in the route decision making process from a carrier/vessel operator perspective, and the importance of economies of scale as key for vessels using the longer routes for revenue maximization. Consequently, in this research we hypothesizes the importance of variables related to voyage costs and the interport, interroute and inter-origin competitions as influencers of the soybean traffic demand of the Panama Canal. The key challenge or goal of this

${ }^{4}$ Freight rates for U.S. grains are regularly published by the U.S. Department of Agriculture reports such as Bulk Grain Ocean Dashboard. (https://agtransport.usda.gov/stories/s/Bulk-Grain-Ocean-Dashboard/hwhqeta9/) and the Grain Transportation Report (weekly report), USDA- AMS (https://www.ams.usda.gov/ services/transportation-analysis/gtr-datasets). In the latter address you may find weekly data for grains inspections (including soybeans) by U.S. port region.

${ }^{5}$ We have identified very few transits with grains from the U.S. Gulf to East Asia through the Suez Canal. ${ }^{6}$ The time frame of the study was from July 1, 2017 and September 30, 2018. Bypasses were mainly through the Cape of Good Hope, in Panamax vessels and destined to China.

${ }^{7}$ A key requirement for Panamax Plus and Neopanamax bulkers includes adequate chocks and bits for towing and mooring at the Neopanamax locks, as explained in NT Notice to Shipping N-1-2019, pp. 38-46. 
paper is to find regressors that represent voyage costs and these three competitions, incorporating them as part of the soybean demand model through the Panama Canal.

Even though there are previous studies related to the U.S. grain production and exports versus competitors, in reality there is a lack of research specific to the Panama Canal grain trade, particularly soybeans through the Panama Canal, and much less studies about the specific factors impacting soybean traffic through the waterway. For the sake of gaining a better understanding of the factors that may impact soybean traffic through the Panama Canal-- especially more insights about the declining grains and soybeans movements since Fiscal Year 2015-- this study is attempting to fit a global demand model for soybean cargo through the waterway --using Ordinary Least Square (OLS) as the estimation procedure-- as a derived demand from the overall soybean demand, including demand in East Asia. As part of East Asia, China is the largest market for soybeans; thus highlighting the importance of an estimation of a global demand model for soybean traffic through the waterway. The derived demand for oceangoing soybean transportation stems from the ultimate demand for high proteins in East Asia, which necessitates feedstocks, such as soybean byproducts, for meat production. As the level of income in East Asia increases, especially in China, the higher is the consumption of animal protein and oils derived from soybeans, hence the need to import soybeans in oceangoing vessels.

To estimate the global demand model for soybean traffic through the waterway, we are attempting to incorporate explanatory variables -if statistically significant and with the expected sign-, such as Panama Canal effective toll rates, freight rates variables (U.S. Gulf- Asia and Pacific Northwest freight rates, Baltic Dry Index), bunker costs, soybean export inspections from the U.S. Gulf and Pacific Northwest, U.S. Gulf soybean basis level, Brazil's soybean exports and the U.S. dollar index. This research is also estimating the toll rate elasticity of vessels transporting soybeans via the Panama Canal. This choice of explanatory variables originates from the review of the literature related to the demand and transportation of grains, from voyage cost considerations, the few studies directly involving the Panamanian route, and the understanding of soybean transportation as a derived demand for feedstock.

For our analysis, data used to estimate the global demand model for soybean through the Panama Canal come from several open sources such as the U.S. Department of Agriculture, Brazil's Secretariat of Foreign Trade (SECEX) and from Panama Canal transit information on a monthly basis. Although the statistics are in different time spans and periodicities, the data for this study was set between January 1997 and September 2019 for the monthly dataset, and between the second quarter of 1997 and the four quarter of 2019 (from the Panama Canal fiscal year perspective) for the quarterly dataset, taking into consideration the beginning date of the soybean basis information because it is the shortest time series.

As part of this study to find out the factors that go into play in deciding whether or not to use the Panama Canal route, this paper first reviewed the more relevant literature related to the transportation of U.S. grains, in conjunction with the maritime transportation of U.S. grains and soybeans to East Asia, including China, in order to support the estimation methodology and regressors for our soybean demand model. Secondly, we will present the models based on the framework of voyage costs and interroute, interport and interorigin competitions, that is, in terms of the hypothesized 
explanatory variables, as well as detailed explanation of the datasets and sample for the study. Thirdly, we would analyze and provide the main results of our research and contribution, by which an estimated soybean demand model using quarterly data in logarithm form renders the best fit and includes most of the hypothesized variables. At the end --and depending on the significance of explanatory variables-- the main conclusions, contributions and limitations of this research will be presented. The paper will discuss the future of soybean traffic through the waterway, including the possibilities of alternative routes and sources for this trade.

\section{Literary review}

The following is the literature review that provides the backbone for our research regarding the methodology to estimate the global demand model for soybeans through the Panama Canal as a derived demand, taking into account voyage cost calculations as well as the search for appropriate proxies for the inter-origin, interport and interroute competitions against the waterway. In other words, this review will not only lend support to our choice of explanatory variables but will underline the few studies on the Panama Canal, not to mention the limited literature about estimating a demand model for any commodity through the waterway, including grains. However, any analysis of the grain and soybean flows through the Panama Canal must begin with the understanding of the interior transportation of U.S. grains to understand the mechanics of the U.S. grains domestic transportation. For example, Chang et al. (2019) provided important updated information related to the modal share of U.S. grain transportation from the interior of the U.S. grain producing regions to export elevators. Related to barge rates through the Mississippi River and the influence of international grain demand on barge demand, it is important the studies by Wetzstein et al. (2019) and Yu and Fuller (2005) about the importance of competitive barge rates in a grain market characterized by high volumes and low margins, and concluding that own-price elasticity of grain barge rates is elastic in the long run. Barge rate costs are important components of the Louisiana export bids for delivery to Gulf export elevators, especially the CIF barge to Louisiana Gulf (Mississippi River). ${ }^{8}$ These are one of the components of the interport competition within the United States.

Pertinent to the interior grain transportation of the United States and interport competition, DeVuyst et al. (2009) developed a methodology for risk quantification for commodity flows and showed that delay costs, changes in demand across countries and internal grain consumption are factors that affect grain shipments. Those factors may impact the availability of grains for export. Vachal et al. (1997), Wilson et al. (2005), Sarmiento and Wilson (2005) and Ndembe (2015) discussed the importance of deregulation, pricing and innovation in the bidding process for railroad cars allocation for grains. The rail cars allocation after deregulation and the development of unit and shuttle train services for grains are important competitive factors in the interport competition between the U.S. Gulf versus PNW. Railroad efficiency influences export bids and basis for grains delivered to U.S. Gulf and PNW export elevators. Likewise, the table of shuttle and unit trains to U.S. Gulf, PNW and other destinations- published weekly by

${ }^{8}$ Daily CIF barge to Louisiana Gulf (Mississippi River) is readily available from the U.S. Department of Agriculture using the following link: https://www.ams.usda.gov/mnreports/jo_gr112.txt 
the USDA's Grain Transportation Report (USDA-GTR)-, allow us to approximate a "contested area" where "competition" for grains between U.S. Gulf vs the Pacific Northwest occurs for grains originating in the U.S. hinterland, areas more than 200 miles away from the Mississippi river barge system (Ho and Bernal 2018a) (Fig. 3). ${ }^{9}$ Grains allocated to the U.S. Gulf and East Coast region as a consequence of interport competition is a necessary, although not sufficient, condition for grain flows through the Panama Canal.

There are also important transportation studies related to the cost of U.S. and competitors' ocean grain transportation, that is, inter-origin/inter country competition. For example, Gale et al. (2019) and Salin and Somwaru (2014, 2018) emphasized the interdependence between China, the United States and Brazil in terms of the soybean market, and highlighted the effects of transportation costs on the U.S. market share for soybeans compared to Brazil, quantifying the changes in U.S. market share for soybean over time and assessing the competitiveness of U.S. soybeans in the world market in terms of maritime transportation costs. Those studies are valuable source of information for the global grain industry and the Panama Canal soybean trade in terms of U.S. origin through the waterway and alternatives such as Brazil. Gale et al. (2019) also referred to the impact of Chinese tariffs on U.S. soybean trade volumes to China and the growing Chinese investment in Latin America, especially Brazil and Argentina. ${ }^{10}$ Studies such as Byung and Whistance (2019) indicated the influence of seasonality in the price interaction between U.S. versus Brazilian soybean because of the differences in crop harvest.

Involving the potential generation of grain traffic through the Panama Canal and reinforcing the importance of inter-origin and interport forces, Wilson et al. (2004) developed a spatial optimization model for world grain trade projections based upon long term competitive equilibrium. In the base case result, U.S. corn exports from the Gulf region were expected to increase by about 26 million mt up to 2025, a plus for the Panama Canal. The study also anticipated the growing oilseed demand in China and the increase in Brazilian oilseed production, although not considering the latter as the lowest cost producer compared to the United States. Harris (1983) explained the importance of ocean freight cost as part of the landed price at the importing country, allowing an open grain price comparison -ceteris paribus-, between one region/country versus alternatives, ${ }^{11}$ and how a competitive ocean freight rate (for example from the PNW to Asia), may pull inland grains for exports toward this region. According to the author, in the case of the PNW, the increased demand toward this region may create incentives for more efficient railroad services, such as unit trains.

\footnotetext{
${ }^{9}$ The map with the "contested area" for grains from the U.S. hinterland was first developed for a presentation in the 34th PIANC World Congress, Panama. May 7-12, 2018 in a paper titled "The Importance of the U.S. Inland Transportation and Navigation System for the Panama Canal Grain Trade". It helps to illustrate the geographical allocation of grains from the U.S. interior to export elevators. Shuttle trains are defined by USDA-AMS as a service comprising of $100+$ wagons and unit trains as a service of at least 52 wagons. Source: https://www.ams.usda.gov/sites/default/files/media/GTRGlossaryofTerms.pdf

${ }^{10}$ China has shown interest in infrastructure projects in Latin America, such as rail projects linking Brazil's hinterland with ports and Chinese companies acquiring grains export terminals such as in Santos but other projects have not prevailed.

${ }^{11}$ For example, you can compare landed cost/price for soybeans from the U.S. Gulf to China compared to U.S. PNW to China, and compare Brazil- China landed cost. This comparison is regularly performed by the U.S. Department of Agriculture.
} 


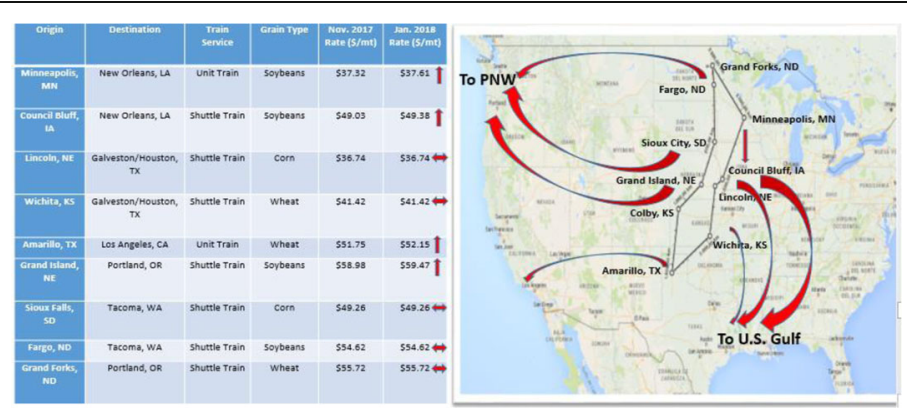

Fig. 3 Shuttle and Unit Trains Grain Shipments and "Contest Area" U.S. Gulf vs PNW. Source: USDA-GTR (Table 4). Drawing by author using USDA- GTR data and google maps

Appertaining to the concept of basis in grain marketing and its importance as a potential explanatory variable for our analysis -defined as the difference between the local cash price (also called spot or flat price) of grain and its nearest future price -, we include the works by Welch et al. (2009), Wilson and Dahl (2010), Kub (2014), Treasure (2015), Hart and Olson (2017) and Bullock and Wilson (2019). Those publications involved basis and pricing patterns across region and over time, basis volatility, and factors such as local supply and demand for grains in the U.S. and international markets, truck, barge and rail costs, storage, crop quality, inventory and seasonality. According to Kub (2014), no grain producer in particular receives the face value posted in the grain future market; therefore, basis is the only way to compare grains on different locations. Regarding basis level at export elevators such as the ones located at the U.S. Gulf, according to Treasure (2015), if demand for U.S. Gulf grains declines -ceteris paribus-, this will likely diminish basis levels at this location compared to other export outlets or, according to Bullock and Wilson (2019), in order to attract more soybeans to an export location, export basis must increase. Similarly, Zhang and Houston (2005) developed an econometric model to predict basis behavior for January and March using interest rate, calculated stock-to-use ratio (SUR), annual volatility for future soybean contracts, the natural logarithm of U.S. ending soybean stocks and the natural logarithm of South America soybean production (SAP). The authors concluded that South America soybean production is statistically significant in the economic evaluation models and, as the expectation of a good South America soybean harvest increases, U.S. soybean basis for January and March is forecast to decrease as per the expected negative sign of the study, providing a relationship between U.S. soybean basis and inter-origin competition.

About the estimation of soybean demand, estimation procedure, potential regressors and model specification for the soybean demand model through the Panama Canal, we are including the work by Saghaian et al. (2014) in which separate import demand functions for U.S. corn and soybeans were estimated for Japan, China and the European Union (EU). This study used log-linear equations, hence being able to calculate price, cross price and income elasticities. Explanatory variables included the price for soybeans and corn (in U.S. dollar); GDP for Japan, China and EU representing income for each country/region; exchange rates and pig and poultry inventory. Konandreas et al. (1978) estimated demand functions for U.S. wheat using Ordinary Least Square (OLS), mixed estimation procedure and Conditional Least Square. The five importing regions 
were developed countries, Latin America, Asia, Africa and USSR and Eastern Europe and the list of regressors include effective U.S. export price for wheat, concessional exports, domestic production of wheat by the importing region, effective per capita income and lagged exports. The research used annual observations from 1954 to 1972. Heien and Pick (1991) used quarterly data for soybean and soymeal demand for the European Economic Community (EEC), Eastern Europe and Japan, and estimated an Almost Ideal Demand System (AIDS) (derived from Deaton and Muellbauer (1980)). In this analysis the authors derived a demand equation for soybean and soymeal using as regressors a price index for the soybean products (U.S., Brazil and Argentina), overall price level and gross national product of the importing country. The authors were able to estimate own and cross price elasticities but faced problem in terms of multicollinearity and data accuracy.

Also, there are limited studies related to Panama Canal shipping demand, some focusing mainly on the container market share and the competitiveness of the Panama Canal compared to alternatives, such as Fan et al. (2012), Ungo and Sabonge (2012), Martinez et al. (2016) and Pham et al. (2018). Also, there are works projecting grains and dry bulk cargo with an expanded Canal including Informa Economics (2011) and Nathan Associates (2012), the latter including the growing production and export of grains through the PNW, but neither study estimated an explicit demand equation for grains/soybean. Pertaining to the competitiveness of the waterway and the importance of Canal's transit cost, Fuller et al. (1984) developed a spatial model to test Panama Canal toll rate increases on U.S. grains exports through the U.S. Gulf to Asia and West Coast of Central and South America, assuming a revenue-maximizing Panama Canal administration. This study revealed a relatively inelastic link between U.S. grain flows through the waterway and toll rates, and highlighted the impact of ocean freight rate and port costs between U.S. Gulf versus U.S. PNW grain flows. Depending on the percentage of toll increases, ocean freight rates and port cost differentials-among other factors-, the author projected the amount of grain flows diverted into the U.S. PNW region compared to the U.S. Gulf, that is, interport competition.

Finally and related to the interroute competition against the Panama Canal, Bai and Siu (2019) developed a study on a destination choice model for very large gas carriers (VLGC) originating on the U.S. Gulf. This work applied a logit model and analyzed the effects of the Panama Canal expansion on destination routes. Alternatively, Wilson and Ho (2018) described commodity traffic through the Panama Canal and provided examples of voyage calculations for several market segments -including grains-, comparing the Panama Canal with the Cape of Good Hope route. Other papers involving the dry bulk segment and grains in particular include Ho and Bernal (2018b, 2019), attempting to estimate a demand function and toll elasticity for dry bulkers transiting the Panama Canal, including the Baltic Dry Index (BDI) as one of the regressors in the former, and a logit model to explain the grain movements from the U.S. East and Gulf Coast to East Asia through the Panama Canal versus alternatives in the latter, using limited transit observations from July 1, 2017 to September 30, 2018. In consequence, 1) drawing from previous studies involving variables such as basis, grain inspections, freight rates,

\footnotetext{
${ }^{12}$ Several grain industry reports explain the demand for soybeans, including the U.S. Department of Agriculture's Long Term Projections, March 2019.
} 
alternative sources, U.S. dollar exchange rate and Panama Canal factors; 2) following the recommendation by Ho and Bernal (2019) for further research on the factors impacting grain traffic through the Panama Canal, and 3) trying to fill the gap concerning estimating sea demand for grains and soybeans, we are attempting to fit a global demand model for soybean traffic through the Panama Canal, taking into consideration that ocean transportation demand for grains is mostly derived from the overall supply and demand for feedstock in the importing countries.

\section{Research model, data and methodology for the study} Hypotheses and research model

Soybean is a high protein oilseed that is part of most Asian diets and is a major feed ingredient for poultry, pigs and livestock. According to the USDA, soybean demand is determined by increasing feed demand for poultry and pork production, being the result of growing meat consumption. ${ }^{12}$ As income level and urbanization increases, so the demand for animal protein in the diet. Normally, soybean is imported by East Asian nations and crushed to produce soybean oil and soybean meal. Soybean oil is processed into cooking oil and biodiesel and soybean meal is fed directly to livestock. ${ }^{13}$ Part of the demand for soybean in East Asia is satisfied by the United States, competing against Brazil and Argentina. Brazil is the number one soybean producer with close to $36 \%$ of global production. The U.S. share is about $35 \%$ and Argentina participation is $11 \%{ }^{14}$ From the same source, China is the main importer of soybeans, representing $61.4 \%$ of total imports, followed by the European Union with $9.5 \%$ of global imports. ${ }^{15}$ Because shipping demand for soybean transportation depends on the consumption of soybean at destination and it is driven by meat demand, global soybean traffic through the Panama Canal -including from the U.S. East Coast and Gulf to East Asia-, is a derived demand from soybean consumption. In other words, soybean is an input for the production of meat and the Panama Canal soybean traffic is a reflection of that demand.

In order to estimate our global demand model for soybean traffic through the Panama Canal as a derived demand for soybean consumption, we must attempt to incorporate explanatory variables that may impact soybean traffic through the waterway. Thus, we hypothesized the regressors for our estimation in terms of variables related to voyage costs and interport, interroute and inter-origin/intercountry competition. As previously mentioned, interport competition is the competition between the U.S. Gulf versus U.S. PNW. To estimate soybean traffic through the Panama Canal from the U.S. Gulf to East Asia and other destinations, we must include variables for interport competition. In other words, U.S. soybean exports from the U.S. Gulf area is a "prerequisite" for soybean traffic through the Panama Canal. As a result, it is necessary to incorporate into our research model the difference in soybeans inspections or cargo spread between U.S. Gulf versus U.S. PNW as a predictor for the growing interport

\footnotetext{
${ }^{13}$ There are several other uses for soybean byproducts besides the ones mentioned in the paragraph. An example of the transformation of soybeans into oil and animal feed can be found in https://ncsoy.org/mediaresources/uses-of-soybeans/.

${ }^{14}$ The calculation is for marketing year 2017/18 and comes from the U. S. Department of Agriculture's Oilseeds: World Market and Trade, USDA-FAS, January 2020. Also, many Eastern Asian nations consider other soybean origins besides the United States, Brazil and Argentina. Nonetheless, they are the main sources.

${ }^{15}$ China's share is for marketing year 2017/18 and it is sourced from U. S. Department of Agriculture's Oilseeds: World Market and Trade, USDA-FAS, January 2020.
} 
competition, but keeping in mind that the U.S. Gulf and East Coast to East Asia is the main soybean route for the Panama Canal. When soybean spread is growing, U.S. Gulf flows is larger compared to PNW, meaning a greater probability of soybean flows through the Panama Canal.

Also, as part of the interport competition between the U.S. Gulf exports versus PNW, we are including in our model U.S. Gulf - Japan and PNW- Japan freight rate differentials or freight rate spread as predictors because of the relevance of ocean transportation cost. Harris (1983) explained that ocean freight rates are part of the landed cost of grains at destination and Fuller et al. (1984) assumed that Panama Canal tolls are incorporated into ship costs and are, thus, included in ocean shipping rates for the routes involving the waterway. Thus, as the ocean freight rate spread between the U.S. Gulf versus PNW increases, that is, the cost of transporting soybeans from the U.S. Gulf to Japan increases relative to the PNW to Japan, we should expect fewer soybean flows through the Panama Canal.

Soybean basis for the U.S. Gulf export region is another explanatory variable that must be included in our research model because it reflects the supply and demand of soybeans for exports in the significant interport competition. Ideally, just as the case of the soybean cargo spread between U.S. Gulf compared to U.S. PNW, it would be a better idea to have the soybean basis differential between U.S. Gulf versus U.S. PNW as an explanatory variable. However, information for PNW soybean basis is not readily available as in the case of U.S. Gulf basis. For this reason, we are only incorporating U.S. Gulf soybean basis as predictor in our model and we are assuming it is influenced by both the PNW soybean basis and by alternative sources such as Brazil, as implied by Zhang and Houston (2005) and Bullock and Wilson (2019). With regard to soybean movement through the Panama Canal, it is highly seasonal and closely reflect the U.S. marketing year for the oilseed. Therefore, seasonality must be included as a dummy variable in our model, especially from October to March and it is expected to be positively related to soybean traffic through the Panama Canal (Fig. 4).

Aiming to incorporate the effect of the increasing inter-origin/intercountry competition in our analysis of the Panama Canal soybean traffic- roughly following the concept of including South America soybean production as an explanatory variable as Zhang and Houston (2005), and taking as reference several studies of the U.S. market share for soybeans compared to Brazil-, we are including soybean exports from Brazil to East Asia as a regressor. To the best of our knowledge, information about soybean exports to East Asia -that is China, Japan, South Korea and Taiwan-, are only readily available for Brazil on a monthly basis. Nonetheless, given the importance of Brazil as the main producer and exporter of soybeans, we can assume Brazilian exports as a good proxy for the intercountry competition for our model. As Brazil soybean exports to East Asia increase, Canal's soybean traffic shall be negatively impacted given the fact that a meager 148.1 thousand metric tons of soybeans from Brazil to East Asia has transited through the Panama Canal between fiscal years 2015-19, meaning the vast majority of Brazilian soybeans to East Asia do not involve the waterway. Also, we are incorporating the average U.S. dollar index as an explanatory variable to factor in the relative price of U.S. soybeans compared to alternative sources such as Brazil, seeking to parallel Saghaian et al. (2014). According to basic economic theory, as the exchange rate for the U.S. dollar increases- ceteris paribus-, U.S. soybeans becomes less attractive to 


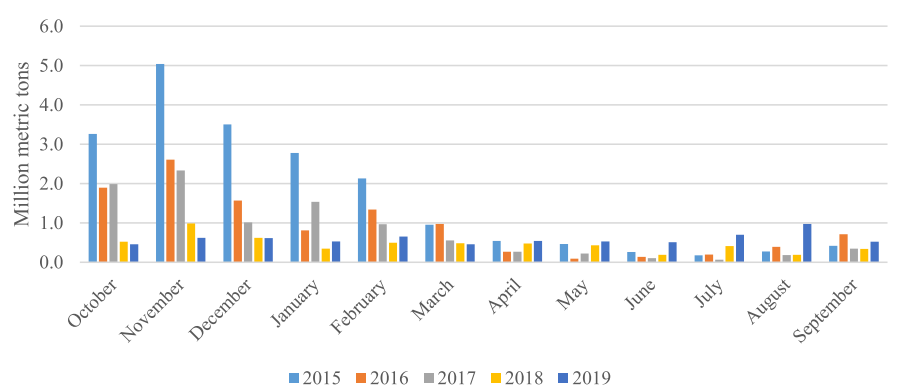

Fig. 4 Seasonality of Soybean Flows through the Panama Canal. Fiscal Year 2015-19. Source: Panama Canal internal database

foreign buyers, thus as the value of the U.S. dollar increases, U.S. soybeans flows through the Panama Canal shall decline, mainly in the U.S. Gulf and East Coast to East Asia route.

For the dry bulk vessel demand and interroute competition between the Panama Canal and alternative routes, for the former we hypothesized the Baltic Dry Index (BDI) for dry bulkers as a reflection of the activity level of bulkers transporting grains and it is assumed to have positive impact on Canal's traffic as this index goes up. In contrast, bunker cost in Houston should reflect part of the voyage cost of transiting the Panama route compared to alternatives and represents the fuel cost of dry bulkers with soybeans out of the U.S. Gulf. For this reason, as fuel price increases, shorter routes such as Panama are more attractive than longer alternatives. Finally, Panama Canal effective toll rate is the most important predictor that we shall include in our demand model for soybeans through the interoceanic waterway. That is, with this variable we want to test how significant Panama Canal transit cost is for grain traffic through the waterway. Based on voyage cost calculations, we can assess the significance of toll rate in the interport competition between soybeans from the U.S. Gulf compared to the PNW, in the interroute competition between soybeans from the U.S. Gulf through Panama compared to alternative routes (i.e. Cape of Good Hope for the export to East Asia) and perhaps the inter- origin competition of U.S. soybeans from the U.S. Gulf compared to Brazil. As Fuller et al. (1984) theorized, the amount of toll rate increase may have a negative impact on the flow of soybeans through the U.S. Gulf in favor of the PNW. Consequently, as Panama Canal toll rates increase, soybean movements through the waterway shall decrease, diminishing the attractiveness of Panama as a route for soybeans.

\section{Data, variables and sample}

For our analysis of a soybean demand function through the Panama Canal, taking into consideration voyage costs and interport, interroute and inter-origin competitions, we are using nine different datasets with different time spans, metrics and periodicities (e.g. daily, weekly, and monthly) to represent the dependent and independent variables of our research. We include open source statistics from different agencies of the U.S. Department of Agriculture (USDA), Brazil's Secretariat of Foreign Trade (SECEX) and Macrotrends.net for average U.S. dollar index, and proprietary data from Clarksons and the Panama Canal Authority (Table 1). Given the different periodicities of the data 
Table 1 List of data sources for the study

\begin{tabular}{|c|c|c|c|c|c|}
\hline Data & Metric & Periodicity & Source & $\begin{array}{l}\text { Beginning } \\
\text { Date }\end{array}$ & Explanation \\
\hline $\begin{array}{l}\text { Global } \\
\text { Soybean } \\
\text { Inspections } \\
\text { U.S. Gulf vs } \\
\text { U.S. PNW }\end{array}$ & $\begin{array}{l}\text { In } 1000 \\
\text { bushels }\end{array}$ & Weekly & $\begin{array}{l}\text { USDA-Grain } \\
\text { Transportation } \\
\text { Report }\end{array}$ & $\begin{array}{l}\text { January 12, } \\
1994\end{array}$ & $\begin{array}{l}\text { To calculate the difference or } \\
\text { "spread" between U.S. Gulf vs } \\
\text { U.S. PNW soybean inspections for } \\
\text { exports }\end{array}$ \\
\hline $\begin{array}{l}\text { U.S. Gulf and } \\
\text { U.S. PNW } \\
\text { Freight Rates }\end{array}$ & $\begin{array}{l}\text { US\$/metric } \\
\text { tons }\end{array}$ & Monthly & $\begin{array}{l}\text { USDA- Grain } \\
\text { Transportation } \\
\text { Report }\end{array}$ & January 1996 & $\begin{array}{l}\text { To calculate the difference of } \\
\text { "spread" between U.S. Gulf- } \\
\text { Japan and U.S. PNW- Japan } \\
\text { freight rates as a proxy to East } \\
\text { Asia. }\end{array}$ \\
\hline $\begin{array}{l}\text { U.S. Gulf } \\
\text { Soybean Basis }\end{array}$ & $\begin{array}{l}\text { US\$/ } \\
\text { bushels }\end{array}$ & Daily & $\begin{array}{l}\text { USDA- } \\
\text { Agricultural } \\
\text { Marketing } \\
\text { Service }\end{array}$ & $\begin{array}{l}\text { July } 25,2005 \\
\text { but complete } \\
\text { series since } \\
\text { April } 32,006\end{array}$ & $\begin{array}{l}\text { Daily (Monday to Friday, except } \\
\text { holidays). }\end{array}$ \\
\hline $\begin{array}{l}\text { Baltic Dry } \\
\text { Index (BDI) }\end{array}$ & $\begin{array}{l}\text { Composite } \\
\text { Index }\end{array}$ & Monthly & Clarksons & January 1985 & $\begin{array}{l}\text { Index for general dry bulk } \\
\text { activity, }\end{array}$ \\
\hline $\begin{array}{l}\text { Houston HSFO } \\
380 \text { cst } 3.5 \% \text { S }\end{array}$ & $\begin{array}{l}\text { US\$/metric } \\
\text { tons }\end{array}$ & Monthly & Clarksons & January 1990 & $\begin{array}{l}\text { High Sulfur Fuel Oil in Houston, } \\
\text { with } 3.5 \% \text { Sulfur }\end{array}$ \\
\hline $\begin{array}{l}\text { Brazil's } \\
\text { seaborne } \\
\text { soybean } \\
\text { exports to } \\
\text { East Asia }\end{array}$ & Metric tons & Monthly & $\begin{array}{l}\text { Secretariat of } \\
\text { Foreign Trade } \\
\text { (SECEX)- Brazil }\end{array}$ & January 1997 & $\begin{array}{l}\text { The summation of Brazilian } \\
\text { soybean exports to China, Japan, } \\
\text { South Korea and Taiwan. }\end{array}$ \\
\hline $\begin{array}{l}\text { U.S. dollar } \\
\text { index }\end{array}$ & Index & Monthly & Macrotrends.net & January 1, 1973 & $\begin{array}{l}\text { Broad price- adjusted U.S. dollar } \\
\text { index by the Federal Reserve, } \\
\text { adjusted for the aggregated } \\
\text { home inflation rates of all } \\
\text { included currencies. } \\
\text { Measurement of U.S. dollar } \\
\text { exchange rate. }\end{array}$ \\
\hline $\begin{array}{l}\text { Effective Toll } \\
\text { Rate Panama } \\
\text { Canal }\end{array}$ & $\begin{array}{l}\text { US\$ per } \\
\text { PC/UMS }\end{array}$ & Monthly & Panama Canal & October 1994 & $\begin{array}{l}\text { Obtained from dividing total toll } \\
\text { amount of vessels loaded with } \\
\text { soybeans, divided by the } \\
\text { Panama Canal Universal } \\
\text { Measurment System (PC/UMS), a } \\
\text { volumetric measurement. }\end{array}$ \\
\hline $\begin{array}{l}\text { Global } \\
\text { Soybean } \\
\text { Flows- } \\
\text { Panama Canal }\end{array}$ & Long tons & Monthly & Panama Canal & October 1996 & Converted to metric tons. \\
\hline
\end{tabular}

proposed for our research, the final statistics representing our dependent and independent variables will be transformed into monthly and quarterly figures in order to run the OLS models.

The global soybean inspections data for exports out of the U.S. Gulf and U.S. Pacific Northwest from the USDA's Grain Transportation Report (GTR) is a weekly publication released every Thursday and represent interport competition because the United States may export soybeans from both regions. To obtain monthly and quarterly statistics, we added both weekly U.S. Gulf and PNW soybeans inspections, respectively, then subtracted PNW from U.S. Gulf inspections to obtain the cargo spread on a monthly and quarterly basis. From the same GTR, monthly ocean freight rates for grains (US\$1 metric tons)- including soybeans- departing from the U.S. Gulf and U.S. PNW regions to Japan is a proxy for the East Asia region, representing the ocean transportation cost for the interport competition. We use the time series of freight rates to Japan because it is larger compared to the much shorter time span for freight rates to China. Freight 
rate differential is obtained by subtracting U.S. PNW- Japan freight rate from U.S. Gulf - Japan freight rate. For the quarterly freight rate differential, we simply calculate a 3 month average. With regard to the daily data for the soybean price basis at U.S. Gulf export elevators, the information is available from the U.S. Department of Agriculture's Agricultural Marketing Service (AMS) and it is an indicator of export demand for soybeans at the U.S. Gulf elevators as explained by Treasure (2015) and Bullock and Wilson (2019). ${ }^{16}$ Daily soybean basis were averaged into monthly and quarterly statistics.

To incorporate factors that may impact the ocean transportation cost of soybeans from the U.S. Gulf to East Asia thorough the Panama Canal or alternatives, mainly the Cape of Good Hope route, we integrated monthly Baltic Dry Index (BDI) data for dry bulkers and monthly bunker cost for Houston (HSFO 380 cst, 3.5\% sulphur) from Clarksons. The BDI series from Clarksons begins in January 1985. On the other hand, the Houston HSFO 380 cst, 3.5\% sulphur series from Clarksons begins in January 1990. Both quarterly BDI and Houston bunker price are averages derived from the monthly data. In terms of the growing inter-origin or inter country competition for U.S. soybean exports, we have monthly Brazilian seaborne soybean export data to East Asia (China, Japan, South Korea and Taiwan) from Brazil's Secretariat of Foreign Trade (SECEX) in metric tons, a series that starts from January 1997. For the quarterly Brazilian seaborne exports, it is a 3 month summation. Also, to take into account the impact of the U.S. dollar's exchange rate on U.S. soybean exports, we add the monthly average U.S. dollar index as provided by Macrotrends.net. This monthly average U.S. dollar index series begins in January 1, 1973. Likewise, the quarterly dollar index is a 3 month average.

Additionally, as the explanatory variable for the effect of the Panama Canal and as a crucial variable in the interroute competition, we included the effective toll rate for all dry bulk vessels transiting the Panama Canal with soybeans as majority cargo. ${ }^{17}$ The effective toll rate is calculated by dividing monthly or quarterly total toll amount paid (U.S. dollar) by vessels loaded with soybeans through the Panama Canal by monthly or quarterly total Panama Canal vessel tons (Panama Canal's Universal Measurement System or PC/UMS) of those vessels with soybeans. PC/UMS tons are the volumetric vessel capacity measure of the waterway. The effective toll rate calculated is in U.S. dollar per PC/UMS. The original total toll rate and total PC/UMS are monthly series beginning in October of fiscal year 1995 (October of 1994 in calendar year). Finally, monthly global soybean flow through the Panama Canal, converted from long tons into metric tons, is the dependent variable for this study and begins in October of fiscal year 1997, which is October 1996 in calendar year. The quarterly global soybean flow is a 3 month aggregation.

Because U.S. Gulf soybean basis begins on April 3, 2006, this is the shortest time series of the entire datasets for the study. This means that the length of time for the monthly, monthly- transformed and the quarterly- transformed data is determined by this time series. Consequently, the beginning date for the monthly and monthly- transformed data is April 2006 while the beginning data for the quarterly transformed data

\footnotetext{
${ }^{16}$ Soybean basis at the U.S. Gulf is in weekdays from Monday through Fridays but excluding holidays. In other words, there is no soybean basis posted on weekends and holidays.

${ }^{17}$ Vessels may transit the Panama Canal with several grain types, so, toll rate is assigned to the largest grain type. However, toll rate is the same regardless of the grain type. For example, the same toll rate for a particular dry bulker will be assessed whether fully loaded with corn, soybean, wheat, sorghum, etc.
} 
is the third quarter of 2006, which includes the months of April through June of 2006. The ending date for the entire datasets in our analysis is September 2019, the last month of fiscal year 2019. Daily U.S. Gulf soybean basis and average U.S. dollar index data, as well as weekly cargo spread inspections data were grouped into monthly and quarterly data. Monthly freight rate spread was also calculated. Once monthly cargo and freight rate spread were calculated, these variables were also grouped into quarters along with the monthly Baltic Dry Index, Houston bunker cost, Brazilian soybean exports to East Asia and Panama Canal effective toll rate. Conversely, seasonality is represented with a dummy variable with a value of 1 for the months of October to March, representing the high soybean traffic months/quarters through the Panama Canal.

\section{Methodology- model specification}

Given the importance of the set of explanatory variables discussed- voyage costs, inter origin/inter country, interroute and interport competition-, previous studies and methodologies, the need to include seasonality and Panama Canal tolls to fit a demand model for soybean traffic through Panama --assuming that ocean transportation demand for soybean is a derived demand for feedstock in the importing countries-- and given the diverse periodicities and availabilities of our data, we are estimating two sets of soybean traffic demand through the waterway using Ordinary Least Square (OLS) as the procedure for estimation: one set is a demand function for soybean through the Panama Canal using monthly and monthly- transformed data (Table 2) and the other estimation is based on quarterly- transformed data (Table 3), parallel to Heien and Pick (1991).

The general specification for our soybean traffic model through the Panama Canalincluding the expected signs for each of the regressors-, is the following:

$$
\begin{aligned}
\text { Soybeanmt }= & \mathrm{F}\left(\mathrm{C}, \text { Tollrate }^{(-)}, \text {Seasonality }^{(+)}, \text {Soybeanbasis }^{(+)}, \text {Gulfpnwspread }^{(-)},\right. \\
& \text {Spreadcargo } \left.^{(+)}, \text {Avgdollarindex }^{(-)}, \text {BDI }^{(+)}, \text {Bunkerhouston }^{(+)}, \text {Brazileastasiamt }^{(-)}\right)
\end{aligned}
$$

where

Soybeanmt: soybean cargo through the Panama Canal in metric tons.

C: Constant term

Table 2 Descriptive statistics for monthly and monthly- transformed data

\begin{tabular}{lll}
\hline Variable & Mean/ Standard Deviation & Highest/Lowest Value \\
\hline Soybeanmt (MT) & $1,031,392 / 1,040,476$ & $5,041,297 / 62,167$ \\
Tollrate (\$/ PC/UMS) & $4.37 / 0.87$ & $5.82 / 2.90$ \\
Soybeanbasis (\$/bushel) & $60.36 / 32.64$ & $212.16 /-9.08$ \\
Gulfpnwspread (\$/MT) & $21.67 / 8.74$ & $60.9 / 8.31$ \\
Spreadcargo (million bushels) & $45,590 / 36,071$ & $148,597 /-14,775$ \\
Avgdollarindex & $91.31 / 6.53$ & $103.2 / 80.2$ \\
BDI & $2297 / 2316$ & $10.843 / 306$ \\
Bunkerhouston (\$/ ton) & $427.9 / 149.9$ & $722.1 / 126.0$ \\
Brazileastasiamt (MT) & $2,736,524 / 2,485,920$ & $9,952,497 / 0$ \\
162 observations & & \\
\hline
\end{tabular}


Table 3 Descriptive statistics for quarterly- transformed data

\begin{tabular}{lll}
\hline Variable & Mean/ Standard Deviation & Highest/Lowest Value \\
\hline Soybeanmt (MT) & $3,074,706 / 2,934,225$ & $11,806,474 / 437,729$ \\
Tollrate (\$/ PC/UMS) & $4.37 / 0.87$ & $5.63 / 2.90$ \\
Soybeanbasis (\$/bushel) & $60.36 / 30.37$ & $154.96 / 5.5$ \\
Gulfpnwspread (\$/MT) & $21.67 / 8.49$ & $52.13 / 9.01$ \\
Spreadcargo (million bushels) & $136,773 / 93,047$ & $329,173 / 9667$ \\
Avgdollarindex & $91.31 / 6.52$ & $102.17 / 80.97$ \\
BDI & $2297 / 2298$ & $10.274 / 358$ \\
Bunkerhouston (\$/ ton) & $457.9 / 148.4$ & $697.1 / 140.1$ \\
Brazileastasiamt (MT) & $8,209,571 / 6,782,727$ & $26,215,027 / 236,413$ \\
54 observations & & \\
\hline
\end{tabular}

Tollrate: Effective toll rate for dry bulkers with soybeans shipped through the Panama Canal.

Seasonality: a dummy variable with a value of 1 for the high season for soybeans through the Panama Canal (October to March); O otherwise.

Soybeanbasis: the difference between the local/spot/flat cash price of soybeans at the U.S. Gulf and its nearest future price.

Gulfpnwspread: the freight rate differential between U.S. Gulf- Japan versus U.S.

PNW - Japan freight rate.

Spreadcargo: the difference in soybeans inspections for exports from the U.S. Gulf versus U.S. PNW.

Avgdollarindex: index representing the average dollar value compared to other currencies.

$B D I$ : Baltic Dry Index. An index of vessel activity for the dry bulk segment, assumed to have an impact on Panama Canal traffic.

Bunkerhouston: the price of High Sulphur Fuel Oil (HSFO) 380 cst, 3.5\% sulphur in Houston, as representative of the cost of fuel in the U.S. Gulf region.

Brazileastasiamt: Brazil soybean exports to China, Japan, South Korea and Taiwan, in metric tons.

Some of the models will include the same set of explanatory variables in logarithm form, except for the regressor for seasonality.

\section{Analysis and results}

The following is the sequence of models for the estimation of a global soybean traffic through the Panama Canal using OLS, based on the monthly, monthly- transformed and quarterly transformed data we have developed for this study. This sequence of models is based on the evaluations of our regressors in terms of statistical significance, expected sign and taking into consideration any violation of the assumptions of the classical normal linear model, such as multicollinearity, autocorrelation and heteroscedasticity. First, we present the results of the estimations based on monthly and monthly- transformed statistics (Table 2), followed by the results of the estimations based on quarterly- transformed data (Table 3). 


\section{Estimation with the monthly and monthly- transformed data (Table 4)}

For the monthly and monthly- transformed data, Model 1 is the general form model attempting to include all the explanatory variables discussed previously for the soybean traffic demand through the Panama Canal. However, predictors such as Gulfpnwspread, BDI, Bunkerhouston and Brazileastasiamt were not statistically significant. Besides BDI, Brazileastasiamt and Bunkerhouston did not post the expected signs and there is evidence of high multicollinearity among several of the regressors, based on the correlation among those predictors and on the Variance Inflation Factor (VIF). Model 2 is an attempt to get rid of all insignificant and wrong signed predictors. This model is much better in terms of expected signs, significant explanatory variables and minimal multicollinearity. However, there is evidence of first order autocorrelation. ${ }^{18}$ Model 3 is Model 2 with first order autocorrelation fixed; ${ }^{19}$ however Tollrate and Soybeanbasis became statistically insignificant after the autocorrelation correction. Model 4 is the logarithm representation of Model 3, with minimal multicollinearity but still with evidence of first order autocorrelation. Nonetheless, Model 4 is in logarithm form and has a better fit than Model 3. Finally, Model 5, also in logarithm form, is derived from Model 4 but with the first order autocorrelation fixed. ${ }^{20}$ Therefore, Model 5 is the best estimation of soybean demand through the waterway using monthly- transformed data in terms of expected signs, significant predictors, minimal multicollinearity plus no evidence of heteroscedasticity. ${ }^{21}$ Additionally, Model 5 provides us with a toll rate elasticity for soybean cargo through the Panama Canal and it is the best estimation of soybean traffic using the monthly and monthly- transformed data.

\section{Estimation with the quarterly- transformed data}

After attempting to estimate soybean demand models based on monthly and monthlytransformed data, the following table includes the sequence of models for the estimation of a global soybean traffic through the Panama Canal, based on the quarterlytransformed data we have developed for this study and parallel to Heien and Pick (1991). As in the previous sequence, we are evaluating our predictors in terms of statistical significance, expected sign and taking into consideration any violation of the assumptions of the classical normal linear model, such as multicollinearity, autocorrelation and heteroscedasticity. In this sequence, Model 9 is the only one in logarithm form (Table 5).

For the quarterly- transformed data, Model 6 is the general form model attempting to include all the explanatory variables previously discussed for the soybean traffic demand through the Panama Canal and with the same issues in terms of wrong signs, statistically insignificant predictors and high multicollinearity as in the case of Model 1 of the monthly-transformed estimation but with no evidence of autocorrelation. In Model 7 we get rid of all insignificant and wrong signed predictors, except Soybeanbasis and Gulfpnwspread with the expected signs. Model 7 is much better in terms of expected signs, significant explanatory variables, lower multicollinearity and no evidence of first

\footnotetext{
${ }^{18}$ The first order autocorrelation was detected using the Breusch-Goftrey Serial Correlation LM Test after checking the Durbin Watson statistic.

${ }^{19}$ Here we used the Hildred-Lu procedure. The first observation was lost because of the differencing process.
} 
Table 4 OLS estimation of soybean traffic using monthly- transformed data

\begin{tabular}{|c|c|c|c|c|c|}
\hline Regressor & Model 1 & Model 2 & Model 3 & Model 4 (Log) & Model 5 (Log) \\
\hline Constant & $\begin{array}{l}5887857^{a} \\
(1536408)\end{array}$ & $\begin{array}{l}4145769^{\mathrm{a}}(745, \\
464.4)\end{array}$ & $\begin{array}{l}4421513^{a} \\
(1042541)\end{array}$ & $\begin{array}{l}17.15576^{\mathrm{a}} \\
(3.300358)\end{array}$ & $\begin{array}{l}13.42014^{\mathrm{b}} \\
(5.199399)\end{array}$ \\
\hline Tollrate & $\begin{array}{l}-244,005.6^{\mathrm{b}}(106 \\
630.3)\end{array}$ & $\begin{array}{l}-157,160.1^{\mathrm{a}}(58, \\
077.16)\end{array}$ & $\begin{array}{l}-104,081.6(88, \\
316.8)\end{array}$ & $\begin{array}{l}-0.812613^{\mathrm{a}} \\
(0.229335)\end{array}$ & $\begin{array}{l}-0.681838^{a} \\
(0.185108)\end{array}$ \\
\hline Seasonality & $\begin{array}{l}790,500.4^{a}(116, \\
500.1)\end{array}$ & $\begin{array}{l}785,348.9^{\mathrm{a}}(104, \\
969.6)\end{array}$ & $\begin{array}{l}592,911.9^{\mathrm{a}}(77 \\
210.10)\end{array}$ & $\begin{array}{l}1.079006^{\mathrm{a}} \\
(0.107222)\end{array}$ & $\begin{array}{l}0.538028^{\mathrm{a}} \\
(0.089732)\end{array}$ \\
\hline Soybeanbasis & $\begin{array}{l}3284.590^{c}(1766, \\
172)\end{array}$ & $\begin{array}{l}4530.940^{\mathrm{a}} \\
(1550.152)\end{array}$ & $\begin{array}{l}2777.432 \\
(1794.398)\end{array}$ & $\begin{array}{l}0.263091^{\mathrm{a}} \\
(0.085413)\end{array}$ & $\begin{array}{l}0.265311^{a} \\
(0.075072)\end{array}$ \\
\hline Gulfpnwspread & $\begin{array}{l}3714.292 \\
(9480.765)\end{array}$ & - & - & - & - \\
\hline Spreadcargo & $\begin{array}{l}16.94435^{\mathrm{a}} \\
(1.904329)\end{array}$ & $\begin{array}{l}16.49192^{\mathrm{a}} \\
(1.565453)\end{array}$ & $\begin{array}{l}15.12522^{\mathrm{a}} \\
(1.467617)\end{array}$ & $\begin{array}{l}0.5220436^{a} \\
(0.060453)\end{array}$ & $\begin{array}{l}0.402326^{\mathrm{a}} \\
(0.050482)\end{array}$ \\
\hline Avgdollarindex & $\begin{array}{l}-53,942.85^{\mathrm{a}}(15 \\
535.92)\end{array}$ & $\begin{array}{l}-41,945.90^{\mathrm{a}} \\
(8409.316)\end{array}$ & $\begin{array}{l}-47,349.49^{\mathrm{a}}(12 \\
088.5)\end{array}$ & $\begin{array}{l}-2.123237^{\mathrm{a}} \\
(0.741618)\end{array}$ & $\begin{array}{l}-1.032270^{c} \\
(0.602624)\end{array}$ \\
\hline $\mathrm{BDI}$ & $\begin{array}{l}-54.30246 \\
(40.93568)\end{array}$ & - & - & - & - \\
\hline Bunkerhouston & $\begin{array}{l}-512.0802 \\
(597.8654)\end{array}$ & - & - & - & - \\
\hline Brazileastasiamt & $\begin{array}{l}0.017885 \\
(0.033225)\end{array}$ & - & - & - & - \\
\hline Observations & 162 & 162 & 161 & 162 & 161 \\
\hline$R^{2}$ & 0.756303 & 0.750016 & 0.632053 & 0.771424 & 0.664786 \\
\hline Adjusted $R^{2}$ & 0.741874 & 0.742003 & 0.620183 & 0.763754 & 0.652983 \\
\hline Durbin Watson & 1.021043 & 1.002577 & 1.716442 & 1.109859 & 1.688698 \\
\hline $\begin{array}{l}\text { Akaike Info. } \\
\text { Criterion }\end{array}$ & 29.25369 & 29.22978 & 28.93424 & 1.524676 & 1.128118 \\
\hline
\end{tabular}

Standard errors in parenthesis. ${ }^{a}$ at $1 \%$ significance level, ${ }^{b}$ at $5 \%$ significance level, ${ }^{c}$ at $10 \%$ significance level

order autocorrelation compared to Model 6 but Gulfpnwspread remains statistically insignificant. In Model 8 we get rid of Gulfpnwspread and obtain a model with the expected signs and significance in the coefficients, low multicollinearity and no evidence of first order autocorrelation and heteroscedasticity. ${ }^{22}$ Finally, Model 9 is Model 8 in logarithm form with expected signs and statistical significance of coefficients, with low multicollinearity and no evidence of heteroscedasticity and no first order autocorrelation. ${ }^{23}$

From the list of models, Model 9 is the best estimation of a global demand model for soybean traffic through the Panama Canal in terms of significant variables with the expected signs, no violation of the classical assumptions for OLS estimation, high $R^{2}$ and adjusted $R^{2}$ and, more importantly, the lowest Akaike Information Criterion (AIC) of all the previously estimated models. ${ }^{24}$ Additionally, Model 9 has the advantage of providing tolls elasticity, which may help to explain the effect of toll rates in the soybean traffic through the waterway.

\footnotetext{
${ }^{20}$ Here we repeated the Hildred- Lu procedure. The first observation was lost because of the differencing process.

${ }^{21}$ We used the Breusch- Pagan- Godfrey Test for heteroscedasticity testing.

${ }^{22}$ Here we used the White test for heteroscedasticity.

${ }^{23}$ For Model 9 we used the White and Breusch- Pagan- Godfrey tests for heteroscedasticity and the BreuschGodfrey Serial Correlation LM test for first order autocorrelation.

${ }^{24}$ Model 9 also has the lowest Schwartz Criterion.
} 
Table $\mathbf{5}$ OLS estimation of soybean traffic using quarterly transformed data

\begin{tabular}{|c|c|c|c|c|}
\hline Regressor & Model 6 & Model 7 & Model 8 & Model 9 (Log) \\
\hline Constant & $17983789^{\mathrm{b}}(7572870)$ & $15202192^{\mathrm{a}}(4814693)$ & $12766553^{\mathrm{a}}(3524515)$ & $\begin{array}{l}21.77896^{\mathrm{a}} \\
(4.184258)\end{array}$ \\
\hline Tollrate & $-1105391^{c}(570,887.2)$ & $\begin{array}{l}-635,635.7^{\mathrm{b}}(267 \\
959.6)\end{array}$ & $\begin{array}{l}-634,014.3^{b}(266, \\
712.5)\end{array}$ & $\begin{array}{l}-0.949883^{\mathrm{a}} \\
(0.297389)\end{array}$ \\
\hline Seasonality & $2279460^{\mathrm{a}}(623,069.1)$ & $2028561^{a}(541,910.7)$ & $2077809^{\mathrm{a}}(535,395.0)$ & $\begin{array}{l}0.950451^{\mathrm{a}} \\
(0.157824)\end{array}$ \\
\hline Soybeanbasis & $14,352.84$ (9408.789) & $13,845.97^{\complement}(8304.076)$ & $16,187.68^{b}(7653.380)$ & $\begin{array}{l}0.209609^{b} \\
(0.103671)\end{array}$ \\
\hline Gulfpnwspread & $-579.4334(47,503.24)$ & $\begin{array}{l}-20,799.43(27 \\
859.90)\end{array}$ & - & - \\
\hline Spreadcargo & $21.64362^{\mathrm{a}}(4.223979)$ & $19.32899^{\mathrm{a}}(3.236470)$ & $19.22035^{\mathrm{a}}(3.218255)$ & $\begin{array}{l}0.569266^{a} \\
(0.105328)\end{array}$ \\
\hline Avgdollarindex & $\begin{array}{l}-1,163,632.9^{\mathrm{b}}(75, \\
575.55)\end{array}$ & $\begin{array}{l}-146,217.8^{\mathrm{a}}(47 \\
444.46)\end{array}$ & $-126,204.0^{\mathrm{a}} 38,964.06$ & $\begin{array}{l}-3.047208^{\mathrm{a}} \\
(0.987651)\end{array}$ \\
\hline $\mathrm{BDI}$ & $-87.24312(204.7646)$ & - & - & - \\
\hline Bunkerhouston & $-918.1969(2892.458)$ & - & - & - \\
\hline Brazileastasiamt & $0.067153(0.072270)$ & - & - & - \\
\hline Observations & 54 & 54 & 54 & 54 \\
\hline$R^{2}$ & 0.822814 & 0.817850 & 0.815690 & 0.869169 \\
\hline Adjusted $R^{2}$ & 0.786572 & 0.794596 & 0.796491 & 0.855541 \\
\hline Durbin Watson & 1.922334 & 2.012731 & 2.029547 & 1.555168 \\
\hline $\begin{array}{l}\text { Akaike Info. } \\
\text { Criterion }\end{array}$ & 31.24291 & 31.15943 & 31.13418 & 0.930419 \\
\hline
\end{tabular}

Standard errors in parenthesis. ${ }^{a}$ at $1 \%$ significance level, ${ }^{b}$ at $5 \%$ significance level, ${ }^{c}$ at $10 \%$ significance level

\section{Discussion}

Using monthly, monthly- transformed and quarterly- transformed data generated from several periodicities and availabilities, and assuming sea transportation demand for soybeans as a derived demand for feedstock, we were able to fit three models with OLS as the estimation procedure, explaining the global soybean traffic through the Panama Canal, using explanatory variables with the correct signs, statistical significance and no violations of the assumptions of the classical normal linear model. These models are Model 5 of the monthly and monthly- transformed data and Models 8 and 9 of the quarterly- transformed data.

In general, models in logarithm form provided the best fit for the global soybean demand using both monthly- transformed and quarterly- transformed data. However, Model 9 of the quarterly- transformed data is perhaps the best fit of all the models presented because of its high $R^{2}$ and adjusted $\mathrm{R}^{2}$, lowest Akaike Information Criterion (AIC) and with the added estimation of the Panama Canal tolls elasticity, which is a very important information for this research and for the relative impact of Canal's cost through the waterway. Also, it is important to highlight the extra advantage of the four models that utilized the quarterly- transformed data in terms of no evidence of autocorrelation. Model 9, nonetheless, seems to include the main factors that may explain the movements of soybean cargo through Panama.

In our attempted estimations, regressors such as BDI, Bunkerhouston and Brazileastasiamt were disregarded because of the wrong expected sign and lack of statistical significance. Specifically, predictors connected to voyage costs and the interroute 
competition, such as $B D I$ and Bunkerhouston, were not significant in our models, similar to the conclusion in the final logit formulation by Ho and Bernal (2019) trying to explain the use of alternative routes to the Panama Canal, but with limited statistics equivalent to only one Panama Canal fiscal year. Likewise, Gulfpnwspread, one of the explanatory variables for the interport competition between the U.S. Gulf vs U.S. PNW, turned out to be statistically insignificant although with the expected sign. Additionally, the most obvious regressor pertinent to the inter-origin/intercountry competition, namely Brazileastasiamt, shared the same fate. However, the inter-origin/intercountry competition is likely present through the dummy variable Seasonality, which was statistically significant and with the correct sign, given the fact that U.S. soybean exports through the Panama Canal to East Asia decline with the beginning of Brazilian's exports to the same destination.

Soybeanbasis, a predictor that reflects the interport competition between U.S. soybeans to the U.S. Gulf versus U.S. PNW, was statistically significant with the expected sign and may be influenced by inter-origin factors such as Brazil soybean production as implied by Zhang and Houston (2005) and Bullock and Wilson (2019). For this reason it is one of the important explanatory variable in our estimation. At the same time, Spreadcargo, an explanatory variable for the interport competition and related to U.S. soybean basis, turned out to be a very significant variable impacting soybean traffic through the Panama Canal. This highlights the importance of understanding the allocation process of soybeans going to the U.S. Gulf or U.S. PNW. Without any doubt, Brazil-through the Seasonality and Soybeanbasis variables-- and U.S. PNW exports are two important competitors that are directly impacting soybean traffic through the waterway. In our modelling, parallel to Saghaian et al. (2014) and related to inter-origin competition, we were able to successfully incorporate exchange rates to explain the price attractiveness of U.S. soybeans compared to alternatives through the Avgdollarindex variable.

Finally, Tollrate is a significant explanatory variable in our analysis from the voyage cost point of view. Particularly, the toll rate elasticity of -0.949883 in Model 9 -very close to unit elastic- gives an idea on how sensitive soybean traffic through the waterway may become to any toll increase. Given the availability of alternative sources for U.S. Gulf soybeans, mainly Brazil and the PNW, and the interroute competition with the Cape of Good Hope and other alternatives from the U.S. Gulf to East Asia, the Tollrate variable may also be considered a factor in the inter-origin, interroute and interport competition related to the Panama Canal. Given this elasticity level as per Model 9 using quarterly- transformed data, the Panama Canal needs to carefully evaluate any change in tolls concerning soybeans. The elasticity value close to -1 from Model $9 \mathrm{em}$ phasizes the narrowing options for the waterway in terms of raising toll rates to vessels carrying soybeans, especially to East Asia.

\section{Conclusions and contributions}

This paper has estimated a global demand model for soybean traffic through the Panama Canal using OLS as the estimation procedure, and assuming a derived demand for soybean consumption in need of transportation to the final destination, especially East Asia. For this assessment, we strived to incorporate every possible explanatory variable related to the interactions of voyage cost, interport, interroute and inter-origin 
competition, following the clues of likely regressors from the literature review. We also took into consideration basic economic theory related to the effect of exchange rates on soybean demand as a commodity. At the end, we concluded that the best estimate of a soybean traffic demand through Panama is Model 9 in logarithm form using quarterly data, with the added benefit of estimating toll elasticity. Taking into account the limited studies on the grain demand through the waterway, this work is a contribution in the field, particularly regarding the explanatory variables impacting soybean traffic through the Panama Canal. Also, an important spin-off of this research is that its methodology may be applied to other grain traffic demand estimations such as corn, sorghum, and so on. This, however, depends on the availability of data and whether the data available is statistically significant.

As far as limitations are concerned, although this study may draw conclusions about the importance of voyage costs, exchange rates and the interplay of interport, interroute and inter-origin competitions, not all the originally proposed explanatory variables for the research were significant to explain soybean traffic through Panama. For example, Brazileastasiamt, the most obvious regressor for the inter-origin competition against the Panama Canal route, was not significant. Similarly Gulfpnwspread for the interport competition, and BDI and Bunkerhouston for dry bulk activity and voyage cost, respectively, were not significant. Nevertheless, the rest of the explanatory variables seems to well represent the interaction impacting the global soybean traffic through the waterway. Conversely, more statistics on the U.S. Gulf soybean basis could be important in a future update, especially given its importance in the model specifications proposed, being the shortest time series in our research. Also, a possible improvement for a future estimation could be incorporating the spread between U.S. Gulf versus U.S. PNW soybean basis, if the latter data is available. On the other hand and as a future work, perhaps a revamped Ho and Bernal (2019) logit model estimation of soybeans from the U.S. Gulf and East Coast to Asia using the Panama Canal versus alternative routes, but with different regressors and a larger sample data, could provide a better evaluation of the factors impacting interroute competition.

In terms of the effective toll rate coefficient in Model 9, with the elasticity close to 1, the Panama Canal perhaps needs to attempt a more assertive toll policy focused on encouraging more soybean traffic, most likely through the panamax locks, or allowing more soybean vessels through the neopanamax locks but in competition with other vessel types that also utilized the expanded Canal, namely container, tankers, LNG or LPG vessels. However, given the fact that daily transit slots through the neopanamax locks are very limited, dry bulkers with soybeans compete directly with vessel types that pay higher tolls, such as container vessels. Another factor to be taken into consideration for future panamax transits with grains through the expanded Canal is the amount of ships retrofitting with adequate chocks and bits to comply with the requirements of the neopanamax locks. On the other hand, from Ho and Bernal (2019), we understand that even during the high season for soybean traffic through Panama, many vessels from the U.S. Gulf to East Asia opted the Cape of Good Hope in significant numbers instead of the Panama Canal route, therefore any toll increase based on seasonality may be counterproductive. This important interroute competition for the waterway may be reflected in the toll rate estimation. In summary, establishing an assertive toll policy for soybeans is a challenge to say the least. Toll rate is a factor 
carriers/vessel operators consider in the voyage calculation before choosing a route. Once a buyer decides to purchase U.S. soybean from the U.S. Gulf region, and taking into consideration the contracted lot size, time, quality, buyer's inventory management, voyage costs and economies of scale, U.S. soybean from the U.S. Gulf to East Asia may decide the Panama Canal or the Cape of Good Hope route depending on the advantages of either route. ${ }^{25}$

For future studies, other predictors, besides soybean basis spread between U.S. Gulf and PNW, shall be considered, such as crush margin of soybeans in China- the main market for this product-, defined as the difference between the price of final soybean products such as soybean meal and oil minus the price of raw soybean. This crush margin in China, if data is available, may be a good proxy for soybean demand in China and could be included as an explanatory variable in a future estimation of soybean traffic through the waterway. Other potential explanatory variable that may be considered in a future research could be the local market value of the soybean in Asia- if this information is at hand. Overall, the Panama Canal must understand all the elements that impact soybean basis in the U.S. Gulf and PNW, and also issues related to the efficiency of the U.S. and competitors' transportation system, future supply and demand, new areas of production inside the United States and overseas, technological breakthroughs for crop yields, trade agreements and the importance of the "contested area" and grain transportation efficiencies to either the U. S. Gulf or PNW. For these reasons, attendance to seminars, conferences and courses related to this topic is very imperative for the Panama Canal Authority in order to keep updated with market events. All the factors explaining the movements of soybean cargo through the waterway discussed in our paper -and related to the interport, interroute and inter-origin competition- are important to recognize. The world is moving and changing, as a result the Panama Canal shall understand and respond accordingly.

\begin{abstract}
Abbreviations
AIC: Akaike Information Criterion; AIDS: Almost Ideal Demand System; AMS: Agricultural Marketing Service (United States Department of Agriculture); BDI: Baltic Dry Index; C.I.F.: Cost, Insurance, Freight; CST: Centistoke; CWT: Canal Water Time; EEC: European Economic Community; EU: European Union; FAS: Foreign Agricultural Service (United States Department of Agriculture); GDP: Gross Domestic Product; GTR: Grain Transportation Report (United States Department of Agriculture); HSFO: High Sulphur Fuel Oil; LM: Lagrangian Multiplier; MT: Metric tons; OLS: Ordinary Least Square; PC/UMS: Panama Canal's Universal Measurement System; PNW: Pacific Northwest (United States); SAP: South America Soybean Production; SECEX: Secretariat of Foreign Trade (Brazil); SUR: Stock-to- Use- Ratio; US: United States; USDA: United States Department of Agriculture; USSR: Union of Soviet Socialist Republics; VIF: Variance Inflation Factor; VLGC: Very Large Gas Carrier
\end{abstract}

\title{
Acknowledgements
}

The authors are grateful to Jaime Castillo, Max Olivares, Katia Quintero, Xenia Mitchel and Gabriel Murgas from the Panama Canal Authority, as well as Maria Eugenia Sanchez, Valentine Lynch and Dr. William Wilson of North Dakota State University for their valuable contributions. Also, the article processing charge for this work accepted by IAME2020 is supported by China Merchants Energy Shipping.

Authors' contributions

Javier Ho conceived the study. Both authors participated in its design and coordination and performed statistical analysis. Both authors read and approved the final manuscript.

\section{Funding}

None. Waiver granted.

\footnotetext{
${ }^{25}$ The Suez Canal also offers rebates to vessels departing from the U.S. Gulf and East Coast to Asia. However, we have observed very few grain transits from that origin to East Asia for this option.
} 


\section{Availability of data and materials}

The datasets generated during and/or analyzed during the current study are available from the corresponding author on reasonable request. Also, some open data for the study are publicly available and included throughout the publication.

\section{Declarations}

\section{Competing interests}

The authors declare that they have no competing interests.

Received: 14 October 2020 Accepted: 15 March 2021

Published online: 22 July 2021

\section{References}

Bai X, Siu J (2019) A destination choice model for very large gas carriers (VLGC) loading from US Gulf. Energy 174:1267-1275. https://doi.org/10.1016/j.energy.2019.02.148

Bullock D, Wilson W (2019) Factors influencing the gulf and Pacific Northwest (PNW) soybean export basis: an explanatory statistical analysis. Agribusiness and applied economics report no. 788. North Dakota State University, Fargo

Byung M, Whistance J (2019) Seasonal soybean price transmission between the U.S. and Brazil using the seasonal regimedependent vector error correction model. Sustainability 11(19):5315

Chang K, Cafarelli P, Gastelle J, Sparger A (2019) Transportation of U.S. grains: a modal share analysis. U.S. Dept. of Agriculture, Agricultural Marketing Service https:/www.ams.usda.gov/sites/default/files/media/TransportationofUSGrainsModalShare1 978_2016.pdf. Accessed 15 Jan 2020

Deaton A, Muellbauer J (1980) An almost ideal demand system. Am Econ Rev 70(3):312-326

DeVuyst E, Wilson W, Dahl B (2009) Longer-term forecasting and risks in spatial optimization models: the world grain trade. Transp Res E Logist Transp Rev 45(3):472-485

Fan L, Wilson W, Dahl B (2012) Impacts of new routes and ports on spatial competition for containerized imports into the United States. Marit Policy Manag 39(5):1-23

Fuller S, Makus L, Gallimore W (1984) Effects on increasing Panama Canal toll rates on U.S. grain exports. South J Agric Econ 16(02):9-20

Gale, F., Valdes, C., Ash, M., (2019), "Interdependence of China, United States, and Brazil in soybean trade". Report from the Economic Research Service (ERS). OCS-19F-01. https://www.ers.usda.gov/webdocs/publications/93390/ocs-19f-01.pdf?v= 3881. Accessed 2 Dec 2019

Harris MJ (1983) Ocean Fleet shipping rates, capacity, and utilization for grains. National Economics Division, Economic Research Service, U.S. Dept. of Agriculture, Washington, D.C. AGES 830912

Hart C, Olson F (2017) Analysis of grain basis behavior during transportation disruptions and development of weekly grain basis indicators for the USDA grain transportation report. Center for Agricultural and Rural Development, lowa State University, Ames. Staff report 17-SR 111

Heien D, Pick D (1991) The structure of international demand for soybeans products. South J Agric Econ 23(1):1-7

Ho J, Bernal P (2018a) The importance of the U.S. inland transportation and navigation system for the Panama Canal grain trade. In: Proceedings of the 34th PIANC World Congress, Panama

Ho J, Bernal P (2018b) Elastic or not elastic? Attempting to estimate an aggregate demand function for the dry bulkers at the Panama Canal. In: Presented at the International Association of Maritime Economist Conference (IAME) in Mombasa, Kenya

Ho J, Bernal P (2019) Panama Canal vs alternative routes: estimating a logit model for grains. Marit Bus Rev, ahead-ofprint(ahead-of-print). https://doi.org/10.1108/MABR-07-2019-0025

Informa Economics (2011) Panama Canal expansion: impact on U.S. agriculture. Prepared for Soybean Board, U.S. Soybean Export Council and Soy Transportation Coalition, Memphis

Konandreas P, Bushnell P, Green R (1978) Estimation of export demand functions for U.S. wheat exports. West J Agric Econ 31:1-12

Kub E (2014) Mastering the grain markets: how profit are really made. Kub Asset Advisory, Inc., Omaha

Martinez C, Adams S, Dresner M (2016) East coast vs. west coast: the impact of the Panama Canal's expansion on the routing of Asian imports into the United States. Transp Res E Logist Transp Rev 91:274-289. https://doi.org/10.1016/j.tre.2016.04. 012

Nathan Associates (2012) Update and development of the dry bulk market segment study. Nathan Associates, Arlington

Ndembe E (2015) Hard red spring wheat marketing: effects of increased shuttle train movements on railroad pricing in the northern plains. J Transp Res Forum 54(2):1-16

Pham T, Kim K, Yeo G (2018) The Panama Canal expansion and its impact on east-west liner shipping route selection. Sustainability 10(12):4353

Saghaian Y, Reed M, Saghaian S (2014) Export demand estimation for U.S. corn and soybeans to major destinations. In: Selected paper prepared for presentation at the 2014 Southern Agricultural Economics Association (SAEA) annual meeting in Dallas, Texas

Salin D, Somwaru A (2014) Eroding U.S. soybean competitiveness and market shares: what is the road ahead? U.S. Dept. of Agriculture, Agricultural Marketing Service https://www.ams.usda.gov/sites/default/files/media/Eroding\%20U.S.\%20Soybea n\%20Competitiveness\%20and\%20Market\%20Shares\%20What\%201s\%20the\%20Road\%20Ahead.pdf. Accessed 14 Jan 2020

Salin D, Somwaru A (2018) The impact of infrastructure and transportation costs on U.S. soybean market share: an updated analysis from 1992-2017. U.S. Dept. of Agriculture, Agricultural Marketing Service https://www.ams.usda.gov/sites/default/ files/media/SoybeanMarketShare.pdf. Accessed 14 Jan 2020

Sarmiento C, Wilson W (2005) Spatial modelling in technology adoption decisions: the case of shuttle train elevators. Am J Agric Econ 87(4):1034-1045 
Skadberg K, Wilson W, Larsen R, Dahl B (2015) Spatial competition, arbitrage and risk in U.S. soybeans. J Agric Resour Econ 40(3):442-456

Treasure S (2015) The farmer's guide to grain marketing: maximizing profit while minimizing risk

Ungo R, Sabonge R (2012) A competitive analysis of Panama Canal routes. Marit Policy Manage 39(6):555-570

Vachal K, Bitzan J, Baldwin B (1997) Implications of a North American grain marketing system for prairie transportation \& elevators. Fargo Upper Great Plains Transportation Institute, North Dakota State University, Fargo. MPC report no. 97-84

Welch J, Mkrtchyan V, Power G (2009) Predicting the corn basis in the Texas Triangle Area. J Agribus 27(1/2):49-63

Wetzstein B, Florax R, Foster K, Binkley J (2019) Transportation costs: Mississippi River barge rates. J Commodity Markets 21(C): 100123. Accepted 30 December 2019

Wilson W, Dahl B (2010) Grain pricing and transportation: dynamics and changes in market. In: Agribusiness and applied economics report no. 674

Wilson W, Ho J (2018) Panama Canal. In: Blonigen B, Wilson W (eds) Handbook of international trade and transportation. Edward Elgar Publishing, U.K., pp 628-657

Wilson W, Koo W, Taylor R, Dahl B (2004) "Long-term forecasting of World Grain Trade and U.S. Gulf Exports". Submitted to the Transportation Research Board for publication in Transportation Research Record. NETS (navigation- economicstechnologies). July 30, 2004. IWR Report 04-NETS-P-05. For the Institute for Water Resources U.S. Army Corps of Engineers Alexandria, Virginia. www.corpsnets.us

Wilson W, Koo W, Taylor R, Dahl B (2005) Long-term forecasting of world grain trade and U.S. gulf exports. Transp Res Rec 1909:22-30

Yu T, Fuller S (2005) The measurement of grain barge demand on inland waterways: a study of the Mississippi river. J Transp Res Forum 44(1):27-39

Zhang R, Houston J (2005) Effects of price volatility and surging south American production on short-run basis dynamics. In: Paper presented at the NCR-134 conference on applied commodity price analysis, forecasting, and market risk management, St. Louis, Missouri, April 18-19, 2005

\section{Publisher's Note}

Springer Nature remains neutral with regard to jurisdictional claims in published maps and institutional affiliations.

\section{Submit your manuscript to a SpringerOpen ${ }^{\circ}$ journal and benefit from}

- Convenient online submission

- Rigorous peer review

Open access: articles freely available online

High visibility within the field

- Retaining the copyright to your article

Submit your next manuscript at $>$ springeropen.com 